\title{
Wkład oficyny wydawniczej Karola Miarki (młodszego) w rozwój ruchu polskiego na Górnym Śląsku na przełomie XIX i XX stulecia
}

Tradycje drukarstwa na Górnym Śląsku sięgają drugiej połowy XVI wieku. Pierwsza drukarnia została założona w roku 1555 w Nysie, kolejna w 1804 r. w Opolu i w 1826 r. w Gliwicach. Były to drukarnie niemieckie, ale wydawano w nich również druki w języku polskim ${ }^{1}$. Polskie drukarnie w tym regionie rozpoczęły swoją działalność w 1845 r. w Mikołowie i w 1847 r. w Piekarach. Koncentrowano się w nich głównie na wydawaniu książek o treści religijnej, modlitewników, śpiewników oraz baśni i przypowieści ${ }^{2}$. Adresowane były do polskojęzycznej ludności śląskiej. Należała ona do najniższych warstw społecznych - czyli byli to robotnicy fabryczni i rolnicy, a ich potrzeby kulturalne ograniczały się przede wszystkim do posiadania i czytania książek religijno-umoralniających. W okresie Kulturkampfu maleńką drukarnię założył w Mikołowie Karol Miarka - nauczyciel z Pielgrzymowic k. Pszczyny, a jednocześnie bojownik o polskość regionu.

W 1869 roku K. Miarka zakupił pismo „Katolik” wychodzące w Chełmnie na Pomorzu od Józefa Chociszewskiego, które rozpoczął wydawać 1 kwietnia 1869 r. w Królewskiej Hucie (dzisiejszy Chorzów) na Górnym Śląsku, regionie stanowiącym integralną część państwa pruskiego. Zmienił jego charakter z pisma katolickiego na polityczne, koncentrując się na zagadnieniu obrony języka polskiego i religii, co w ówczesnych czasach było niezwykle ważne dla rozbudzania poczucia przynależności narodowej ludności śląskiej ${ }^{3}$. Sam podejmował na jego

* Prof. dr hab., Uniwersytet Opolski, Wydział Historyczno-Pedagogiczny, Instytut Nauk Pedagogicznych, Zakład Badań nad Kulturą i Pracą, 45-052 Opole, ul. Oleska 48.

1 S. Wilczek, Wydawnictwo Karola Miarki i jego rola w szerzeniu kultu Mickiewicza, [w:] Adam Mickiewicz. Materiały Śląskiej Sesji Mickiewiczowskiej Wyższej Szkoły Pedagogicznej, Katowice, 10 i 11 kwietnia 1956, Wydawnictwo Śląsk, Katowice 1959, s. 170.

2 Tamże, s. 171.

${ }^{3}$ A. Bar, Karol Miarka jako redaktor „Katolika”, Katowice 1935, s. 18. 
łamach odważne dyskusje, m.in. polemizując z kanclerzem Otto Bismarckiem. Był osobą bezkompromisową, niezwykle odważną, co przyczyniło się do represji ze strony władz pruskich, skazujących go systematycznie albo na kary pieniężne, albo na więzienie. Doprowadziło to do jego trudnej sytuacji materialnej oraz zdrowotnej. Dlatego w 1882 roku przekazał część drukarni swojemu synowi, również Karolowi (urodzonemu w 1856 r.). $)^{4}$ Podobnie jak ojciec, związał on swoje życie z działalnością wydawniczą. Karol Miarka-syn był wtedy 26-letnim mężczyzną nieposiadającym nawet wykształcenia gimnazjalnego. Doświadczenie wydawcy zdobywał poprzez praktykę w drukarni ojca w Mikołowie oraz zwiedzanie drukarń i wydawnictw polskich oraz zagranicznych. Poznawał tam najnowsze dokonania wydawnicze i drukarskie ${ }^{5}$.

W domu rodzinnym spotykał młody Karol wielu polskich działaczy narodowych ze Śląska oraz z innych regionów ziem polskich. Od okresu dzieciństwa wychowywał się w środowisku rodzinnym, w pełni świadomy polskiej przynależności narodowej ${ }^{6}$. Konsekwencją tego było zatrudnianie w prężnie rozwijającym się zakładzie współpracowników zaświadczających o swej polskiej przynależności narodowej ${ }^{7}$. Jego szczególną troskę wzbudzała oświata ludu, co starał się realizować poprzez pracę wydawniczą swojej oficyny. Początki samodzielnej działalności były dosyć trudne, gdyż drukował tylko drobne, zamawiane przez klientów prace, wydając głównie kalendarze religijne cieszące się dużą popularnością $w$ tym regionie.

Kontynuował program wydawniczy ojca, którego celem było zaktywizowanie ludności $w$ życiu społecznym poprzez upowszechnianie oświaty. Jak pisał K. Miarka starszy, „Cały naród - jest przekonany, że podług dzisiejszego organizmu państw europejskich włościanin ważną może odgrywać rolę [...], że dla połączenia wszystkich jednostek i spotężnienia wszystkich sił narodu trzeba się starać o pozyskanie milionów ludu dotąd ciemnego [...], że miliony mogą pożytecznie brać udział w pracy społeczeństwa dopiero wtedy, kiedy włościan i lud prosty

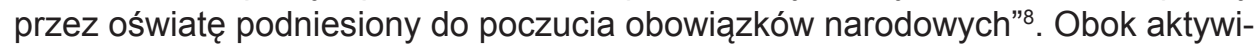
zacji na polu narodowym, w programie wydawniczym dążono też do rozbudzania poczucia godności osobistej ludności górnośląskiej, traktowanej niejednokrotnie dosyć pogardliwie przez ludność niemiecką. Te zadania realizował syn przez 30 lat swojej pracy wydawniczej.

Karol Miarka młodszy był potentatem w zakresie wydawania kalendarzy. Jego staraniem w ostatnich dziesięcioleciach XIX w. i na początku XX stulecia opracowano 11 tytułów różnych kalendarzy. Najważniejszy był „Kalendarz Maryański", mający również mutację przeznaczoną dla ludności zaboru rosyjskiego oraz adresowaną do Polonii amerykańskiej ${ }^{9}$. Był wydawany w latach 1884-1939,

${ }^{4}$ Tamże, s. 174.

5 S. Wilczek, Wydawnictwo..., s. 175.

6 I. Mierzwa, Działalność wydawnicza Karola Miarki młodszego, Opole 1976, s. 26.

7 S. Wilczek, Wydawnictwo..., s. 176.

8 Cyt. za: I. Mierzwa, Działalność..., s. 62.

${ }^{9}$ K. Kossakowska-Jarosz, Polskie kalendarze górnośląskie. Szkic monograficzny, Opole 1994, s. 24. 
tj. przez 56 lat, w zmieniających się warunkach politycznych (także gdy Miarka już nie był właścicielem wydawnictwa). Pierwszy rocznik miał nakład 10 tys., w 1917 r. wydrukowano go w nakładzie 280 tys. egzemplarzy. W ówczesnych czasach stanowiło to rekord wysokości nakładu kalendarza ${ }^{10}$. Konsekwencją tego była stosunkowo niska cena egzemplarza pomimo bardzo starannego wykonania, a stąd dostępność „Kalendarza” dla szerokich kręgów odbiorców.

Od wydawcy zależała treść i dobór zawartości merytorycznej publikacji. Zgodnie z zamierzeniem K. Miarki-syna zadaniem „Kalendarza” było zarówno masowe poradnictwo i dostarczanie rozrywki czytelnikom, jak i zamieszczanie treści z zakresu historii i kultury ojczystej. Na Górnym Śląsku obowiązywał niemiecki system oświaty, nie było możliwości uczenia się po polsku, dlatego kalendarze stanowiły namiastkę podręczników polskich. Starano się czytelników zapoznawać z twórczością Polaków - zarówno uznanych autorów, jak i samouków. Miał „Kalendarz” pełnić funkcje wychowawcze, głównie poprzez propagowanie wiary ojców, czyli religii katolickiej. Kalendarze były ilustrowane, czasem reprodukcjami dzieł artystów, bowiem według Miarki ilustracja w książce ludowej „służy tem lepszemu zrozumieniu przedmiotu, który bezpośrednio przechodząc do umysłu, serca i duszy, tym głębiej zapisuje się w pamięci czytelnika"11. Wiele spośród nich przedstawiało postacie, miejsca i momenty historyczne, m.in. portrety Tadeusza Kościuszki, Hugona Kołłątaja, Juliusza Słowackiego, Fryderyka Chopina; reprodukcje obrazów Jana Matejki - Zaprzysiężenie Unii Litwy z Polską w Lublinie, Wjazd Bolesława Chrobrego do Kijowa; zabytki sakralne - Kościół katedralny w Gnieźnie, Grobowiec św. Wojciecha, sarkofag i relikwiarz w Katedrze Gnieźnieńskiej, Kościół Mariacki w Krakowie i inne ${ }^{12}$.

Niezwykle ważnym zadaniem było upowszechnianie oświaty. W „Kalendarzu Maryańskim” treści układały się „w elementarny kurs z zakresu przyrody, geografii, historii powszechnej, postępu techniki, i kształtowanie obyczajów, w tym zwalczanie szczególnie szkodliwych społecznie przywar i skłonności (np. zatracanie swojskości, ciemnota, pijaństwo), a nadto uczenie efektywnego gospodarowania na roli, w sadzie, finansami domowymi itd."13 Niektóre podejmowały także dyskusje w sprawach społecznych interesów politycznych czy wreszcie budziły przywiązanie do własnego regionu, dokumentując zawsze jego jedność z ojczystą Polską, poświadczaną np. swoistym folklorem ${ }^{14}$.

Wydawanie „Kalendarza Maryańskiego” zapewniło Miarce podstawy finansowe zarówno dla egzystencji rodziny, jak i rozbudowy warsztatu pracy. Był on człowiekiem zapobiegliwym i oszczędnym. Dochody uzyskiwane ze sprzedaży inwestował w rozwój drukarni. W roku 1894 wybudował nowoczesny zakład drukarski w Mikołowie zatrudniający 90 osób. Od 1884 r. zakład przyjął nazwę

10 W. Chojnacki, W. Chojnacki, Bibliografia kalendarzy wydanych w języku polskim poza granicami Polski od roku 1716. Mazury, Śląsk Górny i Dolny oraz Śląsk Cieszyński, Wrocław-WarszawaKraków 1986, s. 32; „Głosy znad Odry” 1918, nr 1, s. 32 i nast.

11 Cyt. za: I. Mierzwa, Działalność..., s. 39.

12 Tamże, s. 131.

13 Tamże, s. 134.

14 K. Kossakowska-Jarosz, Polskie..., s. 33. 
„Wydawnictwo Dzieł Ludowych Karola Miarki w Mikołowie”. Największy jego rozwój nastąpił w latach 90 . XIX stulecia ${ }^{15}$.

K. Miarka był przede wszystkim wydawcą dzieł ludowych adresowanych do ludności regionu przemysłowego. Odmiennie od polskich pisarzy i oświatowców z innych regionów w ówczesnych czasach rozumiał on termin lud, do którego adresowano produkcję wydawniczą. Dla niego nie była to biedna, zacofana i ciemna masa ludności wiejskiej, tylko społeczeństwo w procesie uprzemysłowienia. Napisał w „Kalendarzu Maryańskim”: „Pracować każdy powinien, a jakiego rodzaju jest to praca, to wszystko jedno - chodzi tylko o to, aby człowiek stanowisku swemu godnie odpowiedział. Górnik lub hutnik już to w podziemiach pracujący, już to piekący się przy wielkich ogniach, tłukący kamienie na szosach i drogach publicznych, wystawieni na upał słoneczny i słoty jesienne - są jako ludzie równi ministrowi siedzącemu przy zielonym stoliku, a ich odciski na rękach to najpiękniejsze ordery. [...] Wszyscy muszą pracować, a każda praca jest szacunku godna"16.

Ludność śląska trudniła się zawodami wymagającymi jedynie niskich kwalifikacji, dlatego starał się poprzez swoje wydawnictwa upowszechniać oświatę, dzięki której każdy człowiek mógłby się rozwijać. W „Kalendarzu Maryańskim” pisał: „Starajcie się, aby dzieci wasze miały dobre wiadomości szkolne. Starajcie się, aby córki umiały dobrze gotować, porządek w domu utrzymać, prać, prasować, pończochy robić, szyć i haftować, bo to jest do życia potrzebne"17.

Odbiorcami w znacznej części były kobiety, dla których drukowano różne artykuły i materiały, takie jak: porady, informacje dotyczące zdrowia, prowadzenia gospodarstwa domowego oraz wychowania młodego pokolenia. Publikowano też sentymentalne opowiadania i wiersze. Wszystko było pisane łatwym i komunikatywnym dla odbiorców językiem, co pozwalało docierać do szerokiego kręgu odbiorców. Nie był to język gwarowy, lecz literacka polszczyzna ${ }^{18}$. Ich wpływ na odbiorców był ogromny. Przede wszystkim wdrażały one do czytelnictwa, zapoznawały - poprzez drukowanie opowiadań historycznych - z tradycjami i dziejami narodu polskiego, przybliżały dorobek polskich pisarzy i poetów. Starano się tworzyć wspólnotę wszystkich mówiących po polsku, zachęcając do obrony i pielęgnowania języka ojczystego. Włączano Śląsk w obchody rocznic narodowych, ukazywano również perspektywę odzyskania własnego bytu państwowego.

Według Karola Miarki syna kalendarze miały rozbudzać zainteresowania i dzięki temu pozyskiwać czytelników dla czasopism upowszechniających wiedzę, które nie cieszyły się w regionie większą popularnością. W okresie lat 1885-1906 wydawał on pięć czasopism. I tak miesięcznik religijny „Zdrowaś Maryo”- wydawano od 1885 r. przez sześć lat, dwutygodnik „Missyonarz Katolicki” - tylko przez trzy lata od 1891 r., a czasopisma oświatowo-rozrywkowe „Wolne Chwile (1887), „Przyjaciel Rodzinny” (1894-1896), „Rodzina” (1906-1908) drukowano jedynie przez krótki okres ${ }^{19}$. Na Śląsku wówczas ukazywało się ok. 100 tytułów różno-

15 S. Wilczek, Wydawnictwo..., s. 176.

16 Cyt. za: I. Mierzwa, Działalność..., s. 36.

17 Noworocznik. Z Bogiem zaczynajmy wszystko, „Kalendarz Maryański” 1890.

18 K. Kossakowska-Jarosz, Polskie..., s. 22.

19 Tamże, s. 133. 
rodnych czasopism (polskich i niemieckich), kierowanych do zróżnicowanych kręgów odbiorców, dlatego między wydawcami miała miejsce ostra rywalizacja o czytelnika. Karol Miarka młodszy uważał, że czasopiśmiennictwo pozwala na przemieszanie różnego rodzaju materiałów, „takich, z którymi ludowy czytelnik był już oswojony i do których sięgał z zainteresowaniem oraz trudniejszych, które czytał, ponieważ zapłacił za cały zeszyt"20.

„Wolne Chwile” były w zasadzie czasopismem świeckim, chociaż obok nauki i zabawy podejmowano $w$ nim również problemy religijne. Ukazywały się przez 9 miesięcy w 1887 r. Było to 16-stronicowe czasopismo, na którego zawartość składały się: „powieści, obrazki z życia ludu, artykuły pouczające, żarty i dowcipy, ogłoszenia, a całości dopełniały wiersze i ilustracje"21. Prezentowano teksty pełne grozy, o wątkach sensacyjnych. W większości autorzy byli anonimowi. Ważną rolę dydaktyczną spełniały ilustracje będące często punktem wyjścia dla różnych pouczeń czytelników. Drukując podania ludowe, dążono do budzenia uczuć narodowych poprzez wprowadzanie bohaterów w pozalokalny, szerszy świat. Prowadziło to do poszerzania zainteresowań czytelników nie tylko wspólnotą lokalną, ale i narodową ${ }^{22}$. Nie udało się wydawcy w tak krótkim okresie wydawania pisma wdrożyć w pełni programu oświatowego. Opublikowane materiały dotyczące tego zakresu obejmowały zagadnienia z historii naturalnej, higieny, gospodarki, prezentowano zwyczaje narodów słowiańskich oraz miejsca kultu religijnego za granicą i na ziemiach polskich.

Podobne zagadnienia poruszano na łamach „Przyjaciela Rodzinnego” - pisma ukazującego się w latach 1894-1896. Łączył on problematykę oświatową, rozrywkową z polityczną. Sprawy polityczne zostały wyodrębnione i ukazywały się w samodzielnym dodatku pt. „Kronika Tygodniowa do «Przyjaciela Rodzinnego», najważniejsze wiadomości polityczne, kościelne i społeczne". Redaktorem odpowiedzialnym za ten dodatek był sam Karol Miarka młodszy. Od 1896 r. był wydawany drugi dodatek pt. „Pobudka do szerzenia wstrzemięźliwości. Organ Towarzystwa Szerzenia Wstrzemięźliwości”, co było bezpośrednim włączeniem się w prowadzoną szeroko akcję przeciwko pijaństwu na Śląsku²3.

W „Przyjacielu Rodzinnym” problematyka narodowa wysunięta została na pierwsze miejsce. Było to związane z ogólną sytuacją w tym regionie. Działania germanizacyjne na wszystkich płaszczyznach życia społecznego spowodowały, że cała polska prasa na Górnym Śląsku wzbogacała swoje łamy prezentowaniem dziejów polskich, troszczono się o naukę języka polskiego wśród najmłodszych pokoleń. W czasopiśmie zainicjowano dział opowiadań historycznych, w ramach których publikowano krótkie opowiadania z historii Śląska, prezentowano informacje dotyczące Słowian oraz systematycznie w poszczególnych numerach Dzieje narodu polskiego ${ }^{24}$. W obszernym szkicu przedstawiono region Wielkopolski wraz

20 I. Mierzwianka, Czasopisma oświatowe Karola Miarki młodszego, „Biuletyn Informacyjny Biblioteki Śląskiej" 1972, R. 17, Katowice 1974, s. 92.

21 Tamże, s. 93.

22 Tamże, s. 96.

23 Tamże, s. 102.

24 Tamże, s. 103. 
z charakterystyką jego mieszkańców, Podróż po Warszawie zawierającą ilustrowany opis miasta oraz artykuł Wydobywanie nafty i wosku ziemnego w Galicji25. W ten sposób starano się przybliżyć śląskim czytelnikom życie i tradycje ludności innych regionów Polski. W „Przyjacielu Rodzinnym” opublikowano najbardziej patriotyczną powieść Karola Miarki ojca pt. Petronela. Poczynania wydawnicze w Mikołowie w zakresie wydawania czasopism śledzono m.in. w Galicji. W wydanym w 1913 r. podręczniku dotyczącym pracy oświatowej napisano: „wielką zasługą i krokiem naprzód w działalności zakładu stanowi wydawnictwo klasyków polskich (dalekie zresztą od doskonałości wydawniczej) i album królów. Dział naukowy - reprezentowany był słabo pod każdym względem, na wyróżnienie zasługują Dzieje narodu polskiego, napisane bardzo naiwnie, ale lepiej od wielu innych zarysów"26.

Podobna problematyka była prezentowana w tygodniku „Rodzina”, chociaż głównie koncentrowano się na zagadnieniach oświatowo-rozrywkowych, tj. na dziale literackim, ilustracjach, anegdotach, dowcipach. Problematyka polityczna była pomijana. „Obejmuje powieści historyczne i obyczajowe, opisy i obrazy krajów, miast i ludów, artykuły z czasów współczesnych i naukowe, ciekawe i wesołe opowiadania" - napisano w winiecie tytułowej tygodnika ${ }^{27}$. Program czasopisma miał charakter polsko-katolicki, gdyż „pod każdym względem stać będzie na straży ogniska rodzinnego [...] - «Rodzina» ma być nie tylko dobrym doradcą i przyjacielem, ale służyć również pożytecznej rozrywce. W tym celu pismo będzie zapoznawać z wszystkim, co dzieje się w kraju i za granicą. Redakcja obiecuje, że żadne ważniejsze zdarzenie z życia społecznego nie ujdzie naszej uwagi"28. Było ono kierowane do szerokiego odbiorcy „ażeby zarówno młodzieży, jako też prostaczkom mogło być dostatecznie zrozumiałem"29. W programie oświatowym realizowanym na łamach czasopism wydawanych w Mikołowie na pierwszym planie znajdowała się historia, poprzez którą dążono do rozbudzania świadomości przynależności narodowej.

Próby wydawania czasopism oświatowych przez Karola Miarkę młodszego nie powiodły się. „Kalendarz Maryański” wydawano przez 56 lat, natomiast pisma prezentujące wyższy poziom merytoryczny zawartych w nich treści jedynie krótko - od kilku miesięcy do 3 lat. Było to konsekwencją z jednej strony niezbyt dobrej znajomości literackiej polszczyzny na Górnym Śląsku przez robotników i ludność rolniczą, a z drugiej konkurencji z wydawnictwami niemieckimi.

Dokonująca się w owym czasie gwałtowna urbanizacja Górnego Śląska powodowała, że szkolnictwo powszechne i - coraz szerzej dostępne - zawodowe wpływały na podnoszenie ogólnego poziomu wykształcenia mieszkańców regionu, lecz przystępniejsze i łatwiejsze w odbiorze były dla nich publikacje niemieckie, gdyż ten język opanowywano w szkołach. Próbował to zmienić K. Miarka poprzez przygotowanie serii „Biblioteka Pisarzy Polskich”, wydając m.in. dzie-

25 Tamże.

${ }^{26}$ Przegląd polskich wydawnictw popularnych, [w:] Praca oświatowa, jej zadania, metody, organizacja, Kraków 1913, s. 200-201.

27 Cyt. za: I. Mierzwianka, Czasopisma oświatowe..., s. 108.

28 Tamże, s. 109.

29 Tamże, s. 103. 
ła: A. Mickiewicza, J. Słowackiego, Z. Krasińskiego, W. Pola i W. Syrokomli30. W praktyce mikołowskiego wydawnictwa „teksty bardzo komunikatywnych utworów pisarzy polskich przerabiano «na ludowo»”. Wydano więc „w streszczeniu” Krzyżaków i Dokąd idziesz Panie H. Sienkiewicza, Braci Zborowskich, Dwóch kniaziów H. Rzewuskiego. W podobny sposób streszczono również dzieła pisarzy obcych, jak np. J. Verne"31. Za taki sposób prezentowania dorobku literatury polskiej Wydawnictwo to było krytykowane, gdyż używano słownictwa często gwarowego, prostego, co całkowicie pozbawiało te utwory walorów literackich. Według wydawcy taki sposób prezentacji dorobku polskich pisarzy miał torować drogę do literatury polskiej wyższego poziomu. Wszystkich skrótów dokonano jedynie z powieści historycznych, chcąc w ten sposób spopularyzować historię Polski.

Serię „Nowa Biblioteka Pisarzy Polskich” wznawiano kilka razy przed 1911 r. ${ }^{32}$ Obejmowała ona głównie klasyków literatury polskiej okresu romantyzmu, tj. A. Mickiewicza, J. Słowackiego, I. Krasińskiego, W. Pola, W. Syrokomlę. Miarka przeznaczył ją dla Polonii amerykańskiej i niemieckiej, część dotarła również do Królestwa. Interesujące wydaje się, że te publikacje nie były bezpośrednio kierowane do śląskiego czytelnika. Być może przyczyną jest fakt, wspomnianej wyżej, bardzo słabej znajomości języka literackiego przez ludność górnośląską. Jedynie poezja A. Mickiewicza była poczytna w regionie, gdyż szeroko rozpropagowano ją poprzez czasopiśmiennictwo polskie na Śląsku w związku z setną rocznicą urodzin poety.

W Wydawnictwie Miarki drukowano „Biblioteczkę dla Dziatwy i Młodzieży Polskiej”. Włączyło się ono pod koniec XIX stulecia w walkę o język polski w szkole i na lekcjach religii na Górnym Śląsku. Polskie czasopiśmiennictwo szeroko propagowało prywatne nauczanie dzieci czytania i pisania po polsku. K. Miarka wydał 7 książeczek dla dzieci o objętości do 36 stron, drukując wierszyki, baśnie, opowiastki oraz zamieszczając poradnik do nauki polskiego czytania i pisania. Książeczki te były bogato ilustrowane - niektóre miały kolorowe obrazki. Nie wiadomo, czy cieszyły się dużą popularnością, przypuszczać można, iż nie znalazły masowego odbiorcy. W ich miejsce pojawił się Elementarz polski w dużym nakładzie, drukowany czasami łącznie z Małym katechizmem polskim ${ }^{33}$.

Znaczące miejsce w działalności mikołowskiego wydawnictwa zajmowała literatura religijna. W swoim programie wydawniczym literaturze religijnej przypisywał Miarka szczególne miejsce, głównie w zakresie kształtowania moralności. Uważał, iż należy pogłębiać wiedzę religijną. Napisał: „Nieszczęśliwe koleje, przez jakie naród polski przechodzi, od przeszło lat dwustu, są jedną z przyczyn, dla których dzieła treści religijnej, nie w tym stopniu, jakby pragnąć należało, zajmowały Polaków. Uwaga i dążność narodu, zwrócone ku innej stronie, nie pozwalały iść w tym względzie krok w krok za innymi narodami”34. Twierdził, że „nauka

\footnotetext{
30 Przegląd polskich wydawnictw popularnych..., s. 200.

31 S. Wilczek, Wydawnictwo..., s. 178.

32 Tamże, s. 176.

33 I. Mierzwa, Działalność..., s. 75.

34 Tamże, s. 69; L. Goffine, Książka do oświecenia i zbudowania duszy chrześcijańsko-katolickiej, czyli krotki wykład Lekcyi i Ewangelii na wszystkie niedziele i święta. Podług 54 wydania niemieckiego ks. Otta pomnożone i poprawione przez ks. F. Hattlera, z. 1, Mikołów-Warszawa 1903, s. 3.
} 
wiary świętej musi zejść z tej wysokości, na jakiej przez jeden stan uprawiana była, ku dołowi, do licznych rzesz, by była przystępną nie tylko dla rodaków wykształconych, ale również dla ludu pracującego zupełnie jasną i zrozumiałą"35. W 1890 r. zaczęto drukowanie bogato ilustrowanych Żywotów Świętych Pańskich opracowanych wg ks. Bitschnaua. Do roku 1910 dzieło to doczekało się pięciu poprawianych edycji. Corocznie drukowano 5 tys. egzemplarzy. Żywoty te traktowane były przez czytelników jako podręcznik do nauki języka polskiego, bowiem nie było polskiej szkoły. Natomiast Żywoty według ks. Piotra Skargi opracowane przez Józefa Stagraczyńskiego nie cieszyły się popularnością wśród śląskich czytelników ${ }^{36}$.

W 1909 r. rozpoczęto wydawanie Pisma św. Starego i Nowego Testamentu w przekładzie polskim ks. Jakuba Wujka. Ukazały się jedynie trzy zeszyty, bowiem „na tak długą lokatę kapitału, nie odrzucającego chwilowego zysku, zakład mikołowski nie był przygotowany. Nie pozwalał na to także brak funduszu obrotowego. Ponieważ same dobre chęci nie wystarczyły, przeto zaprzestano wydawania Pisma świętego w zakładzie Karola Miarki" - wspominał jego współpracownik ${ }^{37}$.

Drukowano książeczki do nabożeństwa w ilości 10 tys. egzemplarzy rocznie, Ofiarę mszy świętej - 4 tys. egzemplarzy rocznie. Wspomagano katechetów, wydając podręczniki dla nich, różne książki i broszury w kilkudziesięciotysięcznych nakładach. Do czasu, kiedy wydawnictwem kierował Karol Miarka młodszy, tj. do 1911 r., miało ono charakter religijno-narodowy.

Publikacje Wydawnictwa Karola Miarki rozchodziły się w dużej liczbie egzemplarzy zarówno w Stanach Zjednoczonych, w Królestwie oraz na Górnym Śląsku. Było to efektem dobrego kolportażu, możliwości kupowania dzieł w pojedynczych zeszytach, umiejętnej reklamy. Napisano o nim: „W umiejętności działania na zewnątrz jest niedoścignionym dotychczas wzorem"38.

W 1911 r. kłopoty finansowe zmusiły Miarkę do przekształcenia wydawnictwa mikołowskiego w spółkę akcyjną z ograniczoną odpowiedzialnością, a w 1913 r. wycofał się on z tego przedsięwzięcia ${ }^{39}$.

Wydawnictwo Karola Miarki istotnie wpływało na rozwój czytelnictwa w języku polskim pod koniec XIX i na początku XX wieku, gdyż literatura popularna, religijna i ludowa drukowana była tam w bardzo wysokich nakładach. Niska cena ułatwiała dostęp do niej szerokim kręgom czytelników. Zadania postawione polskiemu wydawnictwu na Górnym Śląsku, stanowiącym integralną część Prus, jeszcze przez ojca Karola, czyli uświadomienie narodowe poprzez literaturę, popularyzacja dziejów Polski, kontynuował syn z wielkim powodzeniem. Włączając się w nurt życia społecznego i politycznego, które na przełomie wieków XIX i XX związane było głównie z walką o język polski w szkole, o podniesienie poziomu intelektualnego ludności śląskiej rodzącego się społeczeństwa przemysłowego, stworzył podstawy do kształtowania i utrwalania się poczucia polskiej tożsamości narodowej.

\footnotetext{
35 Tamże.

36 J. Kwiatkowski, Z siedziby Karola Miarki, „Zaranie Śląskie” 1938, s. 23.

37 Tamże, s. 27.

38 Przegląd polskich wydawnictw popularnych..., s. 200-201.

39 K. Kossakowska-Jarosz, Polskie..., s. 90.
} 